\title{
Hazard, ecological and human health risk assessment of heavy metals in street dust in Dezful, Iran
}

\author{
Fatemeh Sadeghdoust $^{1,2}$, Navid Ghanavati ${ }^{* 2}$, Ahad Nazarpour ${ }^{3}$, Timoor Babaenejad ${ }^{2}$ \\ Michael James Watts ${ }^{4}$, \\ 1- Department of Soil Science, Khuzestan Science and Research Branch, Islamic Azad University, Ahvaz, Iran \\ 2- Department of Soil Science, Ahvaz Branch, Islamic Azad University, Ahvaz, Iran \\ 3- Department of Geology, Ahvaz Branch, Islamic Azad University, Ahvaz, Iran \\ 4- Inorganic Geochemistry, Centre for Environmental Geochemistry, British Geological Survey, \\ Nottingham, UK \\ *Corresponding Author: ghanavati.navid2014@gmail.com
}

\section{Abstract}

This study aimed to investigate the potentially toxic metal $(\mathrm{Pb}, \mathrm{Zn}, \mathrm{Cu}, \mathrm{Cr}, \mathrm{Cd}, \mathrm{Ni}, \mathrm{V}, \mathrm{As}$, and $\mathrm{Co})$ hazard in street dust from Dezful, Iran. For this purpose, we collected 30 samples of street dust from the main pedestrian sidewalks of Dezful. Subsequent heavy metal concentration data for these samples was evaluated using human health risk and potential ecological risk index (RI) assessments. The average toxic metal concentrations for $\mathrm{Pb}, \mathrm{Zn}, \mathrm{Cu}, \mathrm{Cr}, \mathrm{Cd}, \mathrm{Ni}, \mathrm{V}$, As, and Co were 54, 224, 51, 44, 0.4, 46, 38, 3, and 8 ( $\mathrm{mg} / \mathrm{kg})$, respectively. Except for As, V, and Co, the mean concentration value of all heavy metals was several times higher than that of baseline concentrations. Calculations for potential ecological risk (PER) suggested a low street dust ecological risk from $\mathrm{Pb}, \mathrm{Zn}, \mathrm{Cu}, \mathrm{Cr}, \mathrm{Ni}$, and $\mathrm{V}$, while $\mathrm{Cd}$ presented a moderate ecological risk level. The highest hazard quotient (HQ) in children and adults was related to $\mathrm{Pb}$ by ingestion, while the lowest value was for $\mathrm{Cd}$ via inhalation. For all heavy metals, the hazard index (HI) was higher for children than adults, which confirmed the risk of exposure to these potentially harmful heavy metals is higher for children. The cancer risk (CR) value for $\mathrm{Ni}, \mathrm{As} \mathrm{Cd}$ and $\mathrm{Pb}$ for children and adults, were lower than the threshold, 10-6, suggesting that the cancer risk for the majority of heavy metals measured was negligible, but more significant than the threshold for $\mathrm{Cr}$, indicating that the presence of $\mathrm{Cr}$ in street dust requires urgent attention.

Keywords: Heavy metal pollution, Hazard index, Street dust, Spatial distribution, Dezful

\section{Introduction}

Dust is one of the main causes of human exposure to potentially harmful metals in the urban environment (Lu et al., 2014b; Rout et al., 2013; Ghanavati and Nazarpour, 2018). Natural factors contributing to more elevated concentrations of metals in dust include parent material and processes of soil formation, coupled with anthropogenic factors, including industrial activities, traffic, fuel combustion, waste disposal and constructions (Holnicki et al., 2017; Lu et al., 2014a). Potentially toxic metals can affect human health through exposure pathways including direct human contact, transfer to plants and animals, thus entering the human food chain, contamination of surface and groundwater drinking supplies and inhalation (Bourliva et al., 2017; Ander et al. 2016; Nazarpour et al., 2017). Metals accumulate in fat and muscle tissue, and bones, contributing to the prevalence of 
numerous diseases and conditions (Khan et al., 2008). Exposure to street dust containing potentially toxic metals has reported pathways and implications for human health via ingestion, dermal contact, and inhalation over varying periods of time (Nazarpour et al., 2018; Yufeng Jiang et al., 2017b). Accordingly, several studies have been conducted on the human health risks associated with toxic metal contamination in street dust and soil (Ebqa'ai and Ibrahim, 2017; Lin et al., 2015; Dehghani et al., 2017). Children are particularly susceptible to the ingestion of dust via hand to mouth contact (Wei et al., 2015). Therefore, health risk assessment calculations are considered as a tool to assess health outcomes (cancerous and non-cancerous outcomes) and pathways of exposure to risk factors (chemical contaminants, toxic metals, etc.) to inform a risk management strategy (Ahmadi et al., 2015; Ghanavat and Nazarpour, 2016). Behravesh et al. (2015) reported that street dust in Mashhad city (Iran) contained potentially toxic metals such as $\mathrm{Pb}, \mathrm{Cu}, \mathrm{Zn}$ and $\mathrm{Ni}$ at concentrations above background levels, in addition to a positive correlation between toxic metals like $\mathrm{Zn}$ and $\mathrm{Cu}$, as well as $\mathrm{Pb}$ and $\mathrm{Zn}$ to potential sources. For example, fuel consumption as well as wear and tear from vehicle brake linings and tires. Similarly, Ghanavati (2018) reported that the HI for toxic metals in street dust of Abadan, Iran, was higher for children than adults, showing that children were at higher risk of exposure to toxic metals than adults. In both age groups, $\mathrm{Cr}$ had the highest cancer risk index, while $\mathrm{Pb}$ had the lowest value. Likewise, Ravankhah et al. (2015) showed that the average concentrations of $\mathrm{Cd}, \mathrm{Pb}, \mathrm{Ni}, \mathrm{Zn}$, and $\mathrm{Cu}$ in the regions of Aran and Bidgol were higher than the local baseline concentrations. Also, the highest hazard index (HI) in both children and adults was for $\mathrm{Pb}$, while the lowest value was found for $\mathrm{Zn}$. Besides, the $\mathrm{HI}$ of all metals for children older than 17 years and adults were found to be more than 2. Studies by Zhang et al. (2013) in the suburbs of Shanghai showed that the average amount of heavy metal concentrations in the samples gathered from small cities street dust was much higher than the amount of background concentrations found within the soil. Pollution from toxic metals was found to be relatively high, posing serious potential environmental hazards. Over the past few years, large amounts of atmospheric dust have entered Iran through the western borders with Iraq, Saudi Arabia, Syria, and Jordan, which are the main source of dust transfer to Western Iran, especially in Khuzestan province and Dezful city, as the second-largest city in terms of the size and population after Ahvaz in Khuzestan province. Zarasnavdi et al. (2011) reported that Dezful city with an average of 159 days from 1996-2009 has the highest number and duration of summer dusty days in Khuzestan.

Accordingly, this study aimed to undertake a hazard assessment of exposure to potentially toxic metals in street dust of Dezful city by 1$)$ determining the toxic metal concentrations ( $\mathrm{Pb}, \mathrm{Zn}, \mathrm{Cu}, \mathrm{Cd}$, $\mathrm{Ni}, \mathrm{Cr}, \mathrm{As}, \mathrm{V}$ and $\mathrm{Co}$ ) in street dust, 2) source apportionment of metal pollution (natural or anthropogenic), and 3) calculate the potential hazard for human and ecological health through exposure to metals from street dust.

\section{Materials and methods}


Dezful city is located at 32 $50^{\prime} 40^{\prime \prime} \mathrm{N}$ and 48 $20^{\prime} 21^{\prime \prime} \mathrm{E}$ with approximately 443,000 inhabitants in 2016 in south-west Iran-Iraq border; the deserts located in this region are the main sources of dust storms over Iran (Gilavand \& Mohammadbidaghi, 2019). The combustion of fossil fuels like oil and gas, industrial pollution as well as traffic on the city streets have been reported as the main sources of the city pollutants. Thus, it is important to assess the potential ecological and human health risk factors of toxic metals in Dezful street dust in order to better manage the existing contaminants.

\section{Sampling and analysis}

To investigate the concentration of the toxic metal in Dezful, we collected 30 samples of street dust in the dry season in May 2016, from the city's hotspots, squares, main streets, shopping centers, residential areas, sidewalks, and other places where dust had accumulated. Figure 1 shows the distribution map of the sampling points. The street dust samples were selected from 30 points in such a way to cover the area thoroughly. The samples were combined in a mixture of 3 samples at intervals of 5 to $10 \mathrm{~m}$ and weighed approximately $100 \mathrm{~g}$. Surface dust samples were separated with brushes and placed in amber glasses without the interference of any metal tools. They were then sealed with aluminum foil to prevent exposure to the direct light. Dust samples were air-dried, passed them through a 220mesh $(63 \mu \mathrm{m})$, and then stored in polyethylene bags; labeling carried out based on McKenzie et al. (2008).

96

\section{Extraction and analysis of heavy metals}

For each sample, we digested $0.35 \mathrm{~g}$ in $10 \mathrm{ml}$ of Aqua regia $\left(\mathrm{HCl}, \mathrm{HNO}_{3}\right)$ in a ratio of 3: 1 in PTFE Teflon containers at $160^{\circ} \mathrm{C}$ for 6 hours (Ruuskanen et al., 2014) and made up its volume to $50 \mathrm{ml}$ with deionized water. Afterward, the metals $\mathrm{Ni}, \mathrm{Pb}, \mathrm{Cu}, \mathrm{Zn}, \mathrm{Cd}, \mathrm{Cr}, \mathrm{Co}, \mathrm{As}$, and $\mathrm{V}$ were measured by an Atomic Absorption Spectroscopy (AAS, Xplora, and GBC models). To determine the existence of metal ions PerkinElmer Model 3110 atomic absorption spectrometer equipped with PerkinElmer single-element hollow cathode lamps and 10-cm air-acetylene burner was used. The Analytical parameters for PerkinElmer 3110 AAS were; $357.9 \mathrm{~nm}$ wavelength, $0.7 \mathrm{~mm}$ slit width and $12 \mathrm{~mA}$ lamp current for Pb element; $324.7 \mathrm{~nm}$ wavelengths, $0.7 \mathrm{~mm}$ slit width and $15 \mathrm{~mA}$ lamp current for $\mathrm{Cu}$ element; $213.9 \mathrm{~nm}$ wavelength, $0.7 \mathrm{~mm}$ slit width and $15 \mathrm{~mA}$ lamp current for $\mathrm{Zn}$ element; $193.7 \mathrm{~nm}$ wavelength, $0.7 \mathrm{~mm}$ slit width and $380 \mathrm{~W}$ lamp current for As element; $228.8 \mathrm{~nm}$ wavelength, $0.7 \mathrm{~mm}$ slit width and $5 \mathrm{~W}$ lamp current for Cd element; $357.9 \mathrm{~nm}$ wavelength, $0.7 \mathrm{~mm}$ slit width and $25 \mathrm{~mA}$ lamp current for Cr element; $232 \mathrm{~nm}$ wavelength, $0.2 \mathrm{~mm}$ slit width and $25 \mathrm{~mA}$ lamp current for Ni element ( Kariper,2015; Lauenstein and Cantillo, 1998). Standard soil reference material, SRM2711 Montana II (NIST, Canada) was used to measure the accuracy and reproducibility 
127

43

reference materials. The amount of individual metals recovery in SRM 2711 materials was in the range of $88-109 \%$. The comparative percentage difference was less than $10 \%$ among sample duplicates.

\section{Pollution assessment}

\section{Potential Ecological Risk (PER)}

The potential ecological risk of toxic metals was assessed using the method presented by Hakanson (Hakanson, 1980). Many researchers have evaluated the potential environmental hazards of toxic metals in soil and street dust samples using this method (Soltani et al., 2015; Sun et al., 2010). The calculation of potential ecological risk index was as follows:

4

(1)

$$
\begin{aligned}
& \mathbf{C}_{\mathbf{f}}=\mathbf{C}_{\mathbf{S}} / \mathbf{C}_{\mathbf{n}} \\
& \mathbf{E}_{\mathbf{r}}=\mathbf{T}_{\mathbf{r}} \times \mathbf{C}_{\mathbf{f}} \\
& \mathbf{R I}=\sum_{\mathbf{i}}^{\mathbf{n}} \mathbf{E}_{\mathbf{r}}
\end{aligned}
$$

In this equations, $\mathrm{C}_{\mathrm{s}}$ represents the toxic metal concentration in the selected sample, $\mathrm{C}_{\mathrm{n}}$ represents the corresponding toxic metals background value, $\mathrm{T}_{\mathrm{r}}$ represents the toxicity response factor of each toxic metal, which are 30, 5, 5, 5, 2, 1 and 2 for $\mathrm{Cd}, \mathrm{Ni}, \mathrm{Cu}, \mathrm{Pb}, \mathrm{Cr}, \mathrm{Zn}$, and $\mathrm{V}$, respectively (Hakanson, 1980), $E_{\mathrm{r}}$ represents the potential ecological risk of each studied metal. The risk index in equation 3 corresponds to the sum of potential ecological risk for multiple toxic metals. The values of potential ecological risk can be classified as follows: Low $(\operatorname{Er}<40)$, moderate $(40 \leq \mathrm{Er}<80)$, considerable $(80 \leq \operatorname{Er}<160)$, high $(160 \leq \operatorname{Er}<320)$ and very high potential ecological risk $(\operatorname{Er} \geq 320)(Z h a o$ et al., 2014); the contamination levels were classified according to the risk index in four groups: low $(\mathrm{RI}<150)$, moderate $(150 \leq R I<300)$, significant $(300 \leq R I<600)$ and high ecological risk $(R I \geq 600)$.

\section{Health Risk assessment}

Human health risk assessment of carcinogenic or non-carcinogenic toxic metals was conducted as a multi-stage process in two parts based on the US Environmental Protection Agency (USEPA) (Sinha et al., 2007). The average daily dose value (ADD) ( $\mathrm{mg} / \mathrm{kg} /$ day), the risk of exposure to a contaminant by ingestion, inhalation, and dermal contact were estimated using equations 4, 5 and 6 (Bennet et al., 2001): 
148 In which $\mathrm{ADD}_{\text {ing, }} \mathrm{ADD}_{\text {inh, }} \mathrm{ADD}_{\text {dermal }}$ are respectively the average daily metal intake ( $\mathrm{mg} / \mathrm{kg}$-day) by 149 ingestion, inhalation, and dermal contact. $\mathrm{C}$ is the concentrations of metals in the dust ( $\mathrm{mg} / \mathrm{kg}), \operatorname{IngR}$ 150 and InhR are the ingestion rate and inhalation rate of dust ( $\mathrm{mg} /$ day and $\mathrm{m}^{3} /$ day), respectively; EF is 151 the exposure frequency to metals (day/year), ED is the exposure duration to metals (year), BW is the 152 bodyweight of the person exposed to metals $(\mathrm{Kg})$, AT is the averaging time (the period in which 153 exposure is averaged-days) to any amount of metals on a daily basis, PEF is the particle emission 154 factor for metals from dust to air $\left(\mathrm{m}^{3} / \mathrm{kg}\right)$, SA is the skin area exposed to metals $\left(\mathrm{cm}^{2}\right)$, AF is adherence factor ( $\mathrm{mg} / \mathrm{cm}^{2}$-day). ABF is the dermal absorption factor (unit less). The details of each parameter and its values in the risk assessment equations (Wei et al., 2015; Chabukdhara and Nema, 2013; Qing et al., 2015) are given in Table (1). After the calculation of average daily dose value of the metals (ADD) via the three routes of ingestion, inhalation, and dermal contact, hazard quotient (HQ) was calculated based on reference daily intake $\left(\mathbf{R}_{\mathbf{f}} \mathbf{D}_{\mathbf{i}}\right)$ using equation (7).

$$
\mathbf{H} \mathbf{Q}_{\mathbf{i}}=\sum \frac{\mathbf{A D D}_{\mathbf{i}}}{\mathbf{R}_{\mathbf{f}} \mathbf{D}_{\mathbf{i}}}
$$

$\mathrm{HQ}_{\mathrm{i}}$ is the hazard quotient in each intake path, ADDi is the average daily dose value of metal intake by each of the three mentioned routes $\left(\mathrm{mg} / \mathrm{kg} /\right.$ day) and $\mathbf{R}_{\mathbf{f}} \mathbf{D}_{\mathbf{i}}$ is reference daily intake that estimates the maximum risk in the human population exposed daily to heavy metals considering sensitive groups (i.e., adults and children) (Man et al., 2010; Thompson et al., 1992). The values of $\mathbf{R}_{\mathbf{f}} \mathbf{D}_{\mathbf{i}}$ were collected from the US Department of Energy's Risk Assessment Information System (RAIS) (Ferreira-Baptista and De Miguel, 2005). If the average acceptable daily intake $\left(\mathrm{ADD}_{\mathrm{i}}\right)$ is less than the reference daily intake there will be no adverse effects on human health; otherwise, if ADDi is higher than the $\mathbf{R}_{\mathbf{f}} \mathbf{D}_{\mathbf{i}}$, it is likely to have an adverse effect on human health (Kurtz et al., 2001). When the HQ value is $\leq 1$, there will not be an adverse effect, but when $H Q>1$, it is expected to have an adverse effect on human health (Man et al., 2010; Thompson et al., 1992). By summing up the hazard quotient in each intake path (HQi), the HI can be generated to estimate the risk of all contaminated metals according to equation (8):
(1)

$$
\mathrm{HI}=\sum_{\mathbf{i}=\mathbf{1}}^{\mathbf{3}} \mathbf{H} \mathbf{Q}_{\mathrm{I}}
$$

The calculated HI for all elements indicates the severity of undesirable effects in all pathways of human exposure (Staff, 2001). For HI $\leq 1$, there are no apparent adverse health effects of heavy metals, whereas, for $\mathrm{HI}>1$, there will be hostile health effects for residential populations (Bennet et al., 2001). The health risk assessment for carcinogenic heavy metal exposures for both adults and children was calculated through each of the three routes of ingestion, inhalation, and dermal contact by Eq. (9). 
In the above equation, $\mathrm{CR}$ is the cancer risk, and $\mathrm{SF}$ is the carcinogenic slope factor ( $\mathrm{mg} / \mathrm{kg} / \mathrm{day})$. SF captures the assessed daily contaminant intake during a lifetime of exposure to the growing risk of an individual developing cancer ( $\mathrm{Hu}$ et al., 2011). In general, according to the US Environmental Protection Agency, if the carcinogenic risk (CR) is less than $1 \times 10^{6}$ (the probability of one's cancer in

189

190

191

192 every one million people), this risk is negligible, while if the CR is more than $1 \times 10^{4}$, it is harmful and hazardous to human health. CR between the range of $1 \times 10^{-6}$ and $1 \times 10^{-4}$ represents an acceptable risk under the control and monitoring conditions (Wei et al., 2015).

\section{Results and discussion}

\section{Heavy metals concentration}

Heavy metal concentration data in Dezful street dust were compared to background/upper continental crust (UCC) values (Rudnick and Gao, 2003) in Table 2. The average concentration of $\mathrm{Pb}, \mathrm{Zn}, \mathrm{Cu}, \mathrm{Cr}$, $\mathrm{Cd}, \mathrm{Ni}, \mathrm{V}$, As and Co were 54, 224, 51, 44, 0.4, 46, 38, 3, and $8(\mathrm{mg} / \mathrm{kg})$, respectively. Except for As, $\mathrm{V}$, and $\mathrm{Co}$, the mean concentration value for all heavy metals was several times higher than that of the background concentrations, indicating possible anthropogenic input of metals from vehicle wear and tear from brake linings and tires, road wear and the combustion of fossil fuels (Dehghani et al., 2017; Keshavarzi et al., 2015; Najmeddin et al., 2018). Data from this study are comparable to street dust reported by Ghanavati et al. (Ghanavati, 2018) in Abadan, Iran which showed that concentrations of samples of $\mathrm{Pb}, \mathrm{Zn}, \mathrm{Cu}, \mathrm{Cr}, \mathrm{Cd}, \mathrm{Ni}$, As and $\mathrm{Co}$, except for $\mathrm{V}$, were several times higher than the background concentrations. These findings imply that the high concentrations were related to anthropogenic issues such as industrial activities, traffic, (bad) burning of fossil fuels, as well as the construction activities. The study of Mehrasbi et al. (Farahmandkia et al., 2010) on heavy metals in particulate matter in the air of Zanjan showed that the pollution from industrial activities was the most important factor in increasing the concentration of heavy metals in wet and dry atmospheres. Men et al. (Men et al., 2018) reported concentrations of metals in Beijing street dust, eight times above the background levels, with the exception of As and $\mathrm{Mn}$ and $\mathrm{Cd}$. This shows the strong impact of human activities on Beijing's street dust.

Table 3 compares heavy metal concentration in street dust from this study to other cities around the world. The mean concentration of $\mathrm{Pb}$ and $\mathrm{Zn}$ in this study was less than in street dust from Tehran, Isfahan, Nanjing, Hong Kong, Madrid, Newcastle, Oslo, and Amman; however, higher than Shiraz (Iran), Konya (Turkey) and Ottawa (Canada). The mean concentrations of $\mathrm{Cu}$ and $\mathrm{Co}$ in Dezful street dust were less than the mean concentration values of these metals in other cities except Konya. Besides, the mean concentration of $\mathrm{Cr}$ in Dezful street dust samples was less than the mean concentrations of these metals in cities like Shiraz, Isfahan, Nanjing, Hong Kong, and Madrid, while more than Tehran, Amman, Konya, and Ottawa. Additionally, the mean concentration of Cd in Dezful 
street dust was less than the mean concentrations of all cities except Ottawa. Also, the mean concentration of $\mathrm{Ni}$ was lower than its concentrations in Nanjing and Isfahan, while it was more than Shiraz, Tehran, Hong Kong, Newcastle, Oslo, Konya, Amman, Madrid, and Ottawa. The mean concentration of As in Dezful street dust was lower than that of Hong Kong, Nanjing, Newcastle, Isfahan, while higher than that of Ottawa. Moreover, the mean concentration of $\mathrm{V}$ in Dezful was found to be higher than the average concentration value of $\mathrm{V}$ in Hong Kong, while lower than that of Konya. Therefore, high levels of some pollutants in Dezful street dust require consideration of their source, such as vehicle emissions.

\section{Heavy metal source identification}

Statistical correlation between different elements can inform the assessment of the environmental impact and source identification more accurately. Spearman's correlation coefficients were thus used to determine the relationship and correlations between different elements (Table 4). Understanding these relationships can be useful in identifying the source of the element and how it is transmitted in the environment. The correlation coefficient between pollutants showed that the $\mathrm{Pb}$ element had a positive and significant correlation at $(\mathrm{p}<0.01)$ with $\mathrm{Cu}(0.75)$ and $\mathrm{Zn}(0.51)$. The strong positive correlation indicates that these toxic metals originate from common human activity sources. $\mathrm{Cr}, \mathrm{Ni}, \mathrm{V}$, As and Co were found to have significant positive correlation with each other at $p<0.01$. These elements also had a significant positive correlation with $\mathrm{Cd}$ at $\mathrm{p}<0.05$, which indicated another origin. Using principal component analysis (PCA) Bartlett's test of sphericity at $\mathrm{p}<0.001$ was significant; the analysis of Kaiser-Meyer-Olkin Index was 0.772, which confirmed that the toxic metal concentrations were appropriate for PCA. The result of PCA with varimax rotation showed that two Principal Components (PC) accounted for $79 \%$ of the total variance, as illustrated in Figure 2. The first principal component ( $\mathrm{PC} 1$ ) comprised $52 \%$ of the total variance and included $\mathrm{Co}, \mathrm{V}, \mathrm{As}, \mathrm{Cr}, \mathrm{Cd}$, and $\mathrm{Ni}$ metals with the factor loadings $>0.8$. The origins of these heavy metals were likely from anthropogenic sources (for $\mathrm{Cr}, \mathrm{Cd}$, and $\mathrm{Ni}$ metals), such as traffic, wear and tear of vehicle rings and tires, and the use of gasoline as well as natural resources (for Co, V and As metals). The second principal component (PC2), which contained $27 \%$ of the total variance, included $\mathrm{Pb}, \mathrm{Cu}$, and $\mathrm{Zn}$, with the factor loadings $>0.7$ indicating possible anthropogenic sources such as tire wear of vehicles, corrosion of metals, burning of waste and industrial gases (Kong et al., 2012).

\section{Spatial distribution of heavy metals}

The spatial distribution maps of heavy metal concentration values assist in identifying hotspots and pollution sources. In this study, the most concentrated values were related to very high population density and near urban centers, areas near the Andimeshk-Dezful highways, old urban area, city center, areas with high traffic density of Dezful. Areas with relatively low pollution were identified to be those areas developed in the last few decades (compared to the old parts of the city), which had 
low traffic and low population density. The spatial distribution patterns of heavy metals are accordingly shown in Figure 3.

\section{Potential Ecological Risk}

Table 5 and Table 6 show the potential ecological risk (Er) and risk index (RI) values. The trend of Er in dust samples shows $\mathrm{Cd}>\mathrm{Pb}>\mathrm{Ni}>\mathrm{Cu}>\mathrm{Zn}>\mathrm{As}>\mathrm{Co}>\mathrm{V}>\mathrm{Cr}$. Based on the mean value of Er for heavy metals, $\mathrm{Cr}(0.9), \mathrm{V}$ (1), Co (4), As (7), $\mathrm{Zn}$ (7), $\mathrm{Cu}$ (9), Ni (11) and Pb (18) were found to have low potential ecological risk $(\mathrm{Er}<40)$, while $\mathrm{Cd}(59)$ had moderate potential ecological risk $(40 \leq \mathrm{Er} \leq 80)$. The results showed that RI of all samples varied from at least 102 to a maximum of 147 based on the average value of RI (118), the samples are low risk $(\mathrm{RI}<150)$. Also, the results showed that all samples $(100 \%)$ posed low risks. Among the heavy metals studied, the potential ecological risk (Er) of Cd was higher than that of other metals. Accordingly, the environmental contamination caused by this metal, which exists in diesel fuel, oil lubricants, and rubber coatings, should be carefully considered (Foti et al., 2017). In effect, $\mathrm{Cd}$ can be released due to tire wear in hot climates as a result of the friction between roads and vehicle tires. Consequently, the high concentrations of $\mathrm{Cd}$ might be due to high traffic in Dezful. The spatial distribution pattern of potential ecological risk (Er) and risk index (RI) help identify hot areas and pollution sources. In this study, the highest pollution index was found for very high population density and near urban centers, areas near the Andimeshk-Dezful highways, old urban area, city center, areas with high traffic density of Dezful. Areas with low pollution were mostly those developed in the last few decades, which had low traffic and low population density (Fig3, 4).

\section{Health risk assessment}

The assessment of human health risks from the exposed street dust samples from the three main pathways of ingestion, inhalation, and dermal contact was investigated for children and adults. The hazard quotient (HQ) of heavy metals for all three pathways for children and adults is presented in Table 7. The results indicated that the dust exposure pathways of heavy metals for children decreased as ingestion>dermal contact>inhalation. The hazard quotient (HQ) in children's ingestion and inhalation pathways were found to be higher than that of adults, while it was higher for adults through dermal contact. Also, for both age groups, HQ was highest for $\mathrm{Pb}$ metal through ingestion. These findings are comparable to studies conducted by Cheng et al. (Cheng et al., 2018) and Jiang et al. (Yanxue Jiang et al., 2017a). Similarly, Urrutia-Goyes et al. (Urrutia-Goyes et al., 2018) showed that the highest absorption of heavy metals was due to ingestion. Thus, this pathway is of primary concern for the potential exposure and subsequent risk of heavy metals in street dust. The HQ of heavy metals on all three routes of ingestion, dermal contact, and inhalation were found to be less than 1, indicating no harmful effects for humans. Moreover, the lowest risk of HQ in children and adults was for Cd via inhalation. According to Table (7), the hazard index (HI) values of all three pathways for children were 7-2 times higher than those for adults. Also, the HI of all heavy metals in street dust samples for 
children and adults were 0.60 and 0.13 , respectively, which indicates that children are more exposed to the risk of heavy metals than adults. The evaluation of $\mathrm{HI}$ for all three exposure pathways and for each of the metals, separated by children and adults, are presented in Chart (1); the order for children was $\mathrm{Cr}>\mathrm{Pb}>\mathrm{As}>\mathrm{Ni}>\mathrm{Cu}>\mathrm{Zn}>\mathrm{Cd}$, and for adults were $\mathrm{Cr}>\mathrm{Pb}>\mathrm{As}>\mathrm{Ni}>\mathrm{Cd}>\mathrm{Cu}>\mathrm{Zn}$. The HI values of heavy metals were less than 1, indicating that the $\mathrm{HI}$ is low for heavy metals. Accordingly, it revealed that the highest $\mathrm{HI}$ of all three pathways in both groups of children and adults was related to $\mathrm{Cr}$, and the lowest was for $\mathrm{Cd}$ and $\mathrm{Zn}$, respectively. Studies by Keshavarzi et al. (Keshavarzi et al., 2015) on-street dust samples in Shiraz similarly showed that HQ in children was higher than that of adults. In particular, HQ values for children through the ingestion pathway were 2.5 times higher than those in adults. The path of ingestion, followed by dermal contact, seems to be the main source of exposure to the street dust for children and adults, while the HQ was insignificant through breathing. The cancer risk (CR) assessment of heavy metals for children and adults are presented in Chart (2) and follow the order as $\mathrm{Cr}>\mathrm{Ni}>\mathrm{As}>\mathrm{Cd}>\mathrm{Pb}$. Thus, in both age groups, $\mathrm{Cr}$ had the highest $\mathrm{CR}$, while $\mathrm{Pb}$ had the lowest $\mathrm{CR}$. In children, CR values were higher than those in adults. In addition, the CR value for $\mathrm{Ni}, \mathrm{As}, \mathrm{Cd}$ and $\mathrm{Pb}$ for children and adults were lower than the $1 \times 10^{-6}$ threshold (the probability of one person's cancer in one million people), suggesting that we could neglect the cancer risk of toxic heavy metals in the street dust for this study. However, the cancer risk of $\mathrm{Cr}$ was greater than $1 \times 10^{-6}$, which indicates that the cancer risk of $\mathrm{Cr}$ requires urgent attention, particularly as children were more likely to be exposed to human health risks of heavy metals than adults.

\section{Conclusions}

In this study, we examined the concentration values, the ecological and human health risk of the potentially harmful heavy metals $(\mathrm{Pb}, \mathrm{Zn}, \mathrm{Cu}, \mathrm{Cr}, \mathrm{Cd}, \mathrm{Ni}, \mathrm{V}, \mathrm{As}$, and $\mathrm{Co})$ in Dezful street dust. The results indicated that the mean concentration of all heavy metals, except for As, V, and Co, was several times higher than that of the background concentrations; which demonstrates that the pollution source may be related to anthropogenic sources. According to the results of PCA and Pearson's correlation coefficient the major sources of heavy metals in street dust could be grouped into two main sources: As, $\mathrm{Co}$ and $\mathrm{V}$ which mainly come from natural sources, whilst $\mathrm{Pb}, \mathrm{Zn}, \mathrm{Cu}, \mathrm{Cr}, \mathrm{Cd}$ and $\mathrm{Ni}$ originate from anthropogenic sources such as traffic, wear and tear of vehicles rings and tires, the use of gasoline and the combustion of fossil fuels. We found that the average potential ecological risk values, $\mathrm{Er}$, in dust for $\mathrm{Cr}, \mathrm{V}, \mathrm{Co}, \mathrm{As}, \mathrm{Zn}, \mathrm{Cu}, \mathrm{Ni}$, and $\mathrm{Pb}$ are low. Cadmium (59.30), in contrast, showed moderate PER mean values. The order of considered heavy metals exposure pathways for street dust samples is as follows: ingestion>dermal contact>inhalation. The hazard quotients (HQ) of potentially heavy metals in Dezful street dust samples were higher for children as compared to adults. For each metal, the HI value was less than 1, which excludes non-carcinogenic risks for the inhabitants. However, the carcinogenic risk (CR) for all the inhabitants is greater than $1 \times 10^{-6}$. This study may be helpful and valuable for local and national authorities to execute proper actions and 
initiatives in order to reduce the risks and protect the citizens of Dezful, particularly children and other regional studies inform regional cooperation to reduce transport and exposure of potentially harmful metals.

\section{References}

Ahmadi, H., Ahmadi, T., Shahmoradi, B., Mohammadi, S., \& Kohzadi, S. (2015). The effect of climatic parameters on air pollution in Sanandaj, Iran. Journal of Advances in Environmental Health Research, 3 (1).

Behravesh, F., Mahmudi, G. M., Ghassemzadeh, F \& ,.Avaz, M. S. (2015). Determination of heavy metals pollution in traffic dust of mashhad city, and its origin by using "Selective Sequential Extraction" (sse) procedure.

Bennet, D., Chang, S., Cooper, D., Dinan, J., Hofmann, E., Barry, T. (2001). Risk Assessment Guidance for Superfund: Volume 3-Part A, Process for Conducting Probabilistic Risk Assessment'. Washington: U, S. Environmental Protection Agency.

Bourliva, A., Christophoridis, C., Papadopoulou, L., Giouri, K., Papadopoulos, A., Mitsika ,E., et al. (2017). Characterization, heavy metal content and health risk assessment of urban road dusts from the historic center of the city of Thessaloniki, Greece. Environmental geochemistry and health, 39(3), 611-634.

Chabukdhara, M., \& Nema, A. K. (2013) .Heavy metals assessment in urban soil around industrial clusters in Ghaziabad, India: probabilistic health risk approach. Ecotoxicology and environmental safety, 87, 57-64.

Cheng, Z., Chen, L.-J., Li, H.-H., Lin, J.-Q., Yang, Z.-B., Yang, Y.-X., et al. (2018). Characteristics and health risk assessment of heavy metals exposure via household dust from urban area in Chengdu, China. Science of The Total Environment, 619, 621-629.

de Miguel, E., Llamas, J. F., Chacón, E., Berg, T., Larssen, S., Røyset, O ,.et al. (1997). Origin and patterns of distribution of trace elements in street dust: unleaded petrol and urban lead. Atmospheric Environment, 31(17), 2733-2740.

Dehghani, S., Moore, F., Keshavarzi, B., \& Beverley, A. H. (2017). Health risk implications of potentially toxic metals in street dust and surface soil of Tehran, Iran. Ecotoxicology and environmental safety, 136, 92-103.

Ebqa'ai, M., \& Ibrahim, B. (2017). Application of multivariate statistical analysis in the pollution and health risk of traffic-related heavy metals. Environmental geochemistry and health, 39(6), 1441-1456. EPA, U. (1996). Soil screening guidance technical background document, office of solid waste and emergency response. Washington, DC EPA/540, 95.

Farahmandkia, Z., Mehrasbi ,M., Sekhavatjou, M., Hasan, A. M. A., \& Ramezanzadeh, Z. (2010). Study of heavy metals in the atmospheric deposition in Zanjan, Iran.

Ferreira-Baptista, L., \& De Miguel, E. (2005). Geochemistry and risk assessment of street dust in Luanda, Angola: a tropical urban environment. Atmospheric Environment, 39(25), 4501-4512.

Foti, L., Dubs, F., Gignoux, J., Lata, J.-C., Lerch, T. Z., Mathieu, J., et al. (2017). Trace element concentrations along a gradient of urban pressure in forest and lawn soils of the Paris region (France). Science of the Total Environment, 598, 938-948.

Ghanavat, N., \& Nazarpour, A. (2016). Heavy Metals Pollution Assessment of Roadside Soils in the Ahvaz City Junctions.

Ghanavati, N. (2018). Human health risk assessment of heavy metals in street dust in Abadan. Iranian Journal of Health and Environment, 11(1), 63-74.

Ghanavati N, Nazarpour A, Environmental investigation of heavy metals concentration in Ahvaz city street dust, by using Geographical Information Systems (GIS). Enviromental Studies. 2018;44(3):393410 .

Gilavand, A., \& Mohammadbidaghi, M. (2019). Studying the Knowledge Management Components from Viewpoint of the Faculty Members: A Study at the Dezful University of Medical Sciences in Southwest Iran. Future of Medical Education Journal, 9(3), 11-16 
Hakanson, L. (1980). An ecological risk index for aquatic pollution control. A sedimentological approach. Water research, 14(8), 975-1001.

Holnicki, P., Kałuszko, A., Nahorski, Z., Stankiewicz, K., \& Trapp, W. (2017). Air quality modeling for Warsaw agglomeration. Archives of Environmental Protection, 43(1), 48-64.

Hu, X., Zhang, Y., Luo, J., Wang, T., Lian, H., \& Ding, Z. (2011). Bioaccessibility and health risk of arsenic ,mercury and other metals in urban street dusts from a mega-city, Nanjing, China. Environmental Pollution, 159(5), 1215-1221.

Jiang, Y., Chao, S., Liu, J., Yang, Y., Chen, Y., Zhang, A., et al. (2017a). Source apportionment and health risk assessment of heavy metals in soil for a township in Jiangsu Province, China. Chemosphere, 168, 1658-1668.

Jiang, Y., Shi, L., Guang, A.-1., Mu, Z., Zhan, H., \& Wu, Y. (2017b). Contamination levels and human health risk assessment of toxic heavy metals in street dust in an industrial city in Northwest China. Environmental geochemistry and health, 1-14.

Jiries, A. (2003). Vehicular contamination of dust in Amman, Jordan. Environmentalist, 23(3), 205210.

Kariper, İ. A., Üstündağ, İ., Deniz, K., Mülazımoğlu, İ. E., Erdoğan, M. S., and Kadıŏlu, Y. K. (2019). Elemental monitoring of street dusts in Konya in Turkey. Microchemical Journa.l 148, 338345.

Kariper, İ. A. (2015). Determination of $\mathrm{Fe}, \mathrm{Cr}, \mathrm{Pb}$ trace elements by atomic absorption spectrometry after co precipitation with Cadion. Erciyes Üniversitesi Fen Bilimleri Enstitüsü Dergisi, 31(3): 179184.

Keshavarzi, B., Tazarvi, Z., Rajabzadeh, M. A., \& Najmeddin, A. (2015) .(Chemical speciation, human health risk assessment and pollution level of selected heavy metals in urban street dust of Shiraz, Iran. Atmospheric Environment, 119, 1-10.

Khan, S., Cao, Q., Zheng, Y., Huang, Y., \& Zhu, Y. (2008). Health risks of heavy metals in contaminated soils and food crops irrigated with wastewater in Beijing, China. Environmental pollution, 152(3), 686-692.

Kong, S., Lu, B., Ji, Y., Bai, Z., Xu, Y., Liu, Y., et al. (2012). Distribution and sources of polycyclic aromatic hydrocarbons in size-differentiated re-suspended dust on building surfaces in an oilfield city, China. Atmospheric environment, 55, 7-16.

Kurtz, J. C., Jackson, L. E., \& Fisher, W. S. (2001). Strategies for evaluating indicators based on guidelines from the Environmental Protection Agency's Office of Research and Development. Ecological indicators, 1(1), 49-60.

Lauenstein, G., and Cantillo, A. Y. (1998). Sampling and analytical methods of the national status and trends program mussel watch project: 1993-1996 update.

Lin, Y., Fang, F., Wang, F., \& Xu, M. (2015). Pollution distribution and health risk assessment of heavy metals in indoor dust in Anhui rural, China. Environmental monitoring and assessment, 187(9), 565.

Lu, X., Wu, X., Wang, Y., Chen, H., Gao, P., \& Fu, Y. (2014a). Risk assessment of toxic metals in street dust from a medium-sized industrial city of China. Ecotoxicology and environmental safety, $106,154-1.63$

Lu, X., Zhang, X., Li, L. Y., \& Chen, H. (2014b). Assessment of metals pollution and health risk in dust from nursery schools in Xi'an, China. Environmental research, 128, 27-34.

Man, Y. B., Sun, X. L., Zhao, Y. G., Lopez, B. N., Chung, S. S., Wu, S .C., et al. (2010). Health risk assessment of abandoned agricultural soils based on heavy metal contents in Hong Kong, the world's most populated city. Environment international, 36(6), 570-576.

McKenzie, E. R., Wong, C. M., Green, P. G., Kayhanian, M \& ,.Young, T. M. (2008). Size dependent elemental composition of road-associated particles. Science of the Total Environment, 398(1-3), 145153.

Men, C., Liu, R., Xu, F., Wang, Q., Guo, L., \& Shen, Z. (2018). Pollution characteristics, risk assessment, and source apportionment of heavy metals in road dust in Beijing, China. Science of the total environment, 612, 138-147.

Najmeddin, A., Moore, F., Keshavarzi, B., \& Sadegh, Z. (2018). Pollution, source apportionment and health risk of potentially toxic elements) PTEs) and polycyclic aromatic hydrocarbons (PAHs) in 
urban street dust of Mashhad, the second largest city of Iran. Journal of Geochemical Exploration, 190, 154-169. potential ecological risk of some heavy metals in surface soils in the Ahvaz oil-field. Iranian Journal of Health and Environment, 10(3), 391-400.

Nazarpour, A., Ghanavati, N., \& Watts, M. J. (2018). Spatial distribution and human health risk assessment of mercury in street dust resulting from various land-use in Ahvaz, Iran. Environmental geochemistry and health, 40(2), 693-704.

Okorie, A., Entwistle, J., and Dean, J. R. (2012). Estimation of daily intake of potentially toxic elements from urban street dust and the role of oral bioaccessibility testing. Chemosphere 86, 460467.

Qing, X., Yutong, Z., \& Shenggao, L. (2015). Assessment of heavy metal pollution and human health risk in urban soils of steel industrial city (Anshan), Liaoning, Northeast China. Ecotoxicology and environmental safety, 120, 377-385.

Rasmussen, P., Subramanian, K., \& Jessiman, B. (2001). A multi-element profile of house dust in relation to exterior dust and soils in the city of Ottawa, Canada. Science of the Total Environment, 267(1), 125-140.

Ravankhah, N., Mirzaei, R., \& Masoum, S. (2015). Evaluation of Geoaccumulation Index, Contamination Factor, and Principal Component Analysis for Estimating Soil Contamination. Iranian Journal of Health and Environment, 8(3), 345-356.

Rout, T. K., Masto, R., Ram, L., George, J., \& Padhy, P. K. (2013). Assessment of human health risks from heavy metals in outdoor dust samples in a coal mining area. Environmental geochemistry and health, 35(3), 347-356.

Rudnick, R. L., \& Gao, S. (2003). Composition of the continental crust. Treatise on geochemistry, 3, 659.

Ruuskanen, S., Laaksonen, T., Morales, J., Moreno, J., Mateo, R., Belskii, E., et al. (2014). Largescale geographical variation in eggshell metal and calcium content in a passerine bird (Ficedula hypoleuca). Environmental Science and Pollution Research, 21(5), 3304-3317.

Saeedi, M., Li, L. Y., \& Salmanzadeh, M. (2012). Heavy metals and polycyclic aromatic hydrocarbons: pollution and ecological risk assessment in street dust of Tehran. Journal of hazardous materials, 227, 9-17.

Sinha, P., Lambert, M. B., \& Schew, W. A. (2007). Evaluation of a risk-based environmental hot spot delineation algorithm. Journal of hazardous materials, 49(2). 338-345.

Soltani, N., Keshavarzi, B., Moore, F., Tavakol, T., Lahijanzadeh, A. R., Jaafarzadeh, N., et al. (2015). Ecological and human health hazards of heavy metals and polycyclic aromatic hydrocarbons (PAHs) in road dust of Isfahan metropolis, Iran. Science of the Total Environment, 505, 712-723.

Staff, E. (2001). Supplemental Guidance for Developing Soil Screening Levels for Superfund Sites, Peer Review Draft. Washington, DC: US Environmental Protection Agency Office of Solid Waste and Emergency Response, OSWER, 9355.4-24.

Sun, Y., Zhou, Q., Xie, X., \& Liu, R. (2010). Spatial, sources and risk assessment of heavy metal contamination of urban soils in typical regions of Shenyang, China. Journal of hazardous materials, 174(1-3), 455-462.

Thompson ,K. M., Burmaster, D. E., \& Crouch3, E. A. (1992). Monte Carlo techniques for quantitative uncertainty analysis in public health risk assessments. Risk Analysis, 12(1), 53-63.

Urrutia-Goyes, R., Hernandez, N., Carrillo-Gamboa, O., Nigam, K., \& Ornelas-Soto, N. (2018). Street dust from a heavily-populated and industrialized city: Evaluation of spatial distribution, origins, pollution, ecological risks and human health repercussions. Ecotoxicology and environmental safety, $159,198-204$.

Wei, X., Gao, B., Wang, P., Zhou, H., \& Lu, J. (2015). Pollution characteristics and health risk assessment of heavy metals in street dusts from different functional areas in Beijing, China. Ecotoxicology and environmental safety, 112, 186-192.

Yeung, Z., Kwok, R., \& Yu, K. (2003). Determination of multi-element profiles of street dust using energy dispersive X-ray fluorescence (EDXRF). Applied Radiation and Isotopes, 58(3), 339-346. 
484 Zhang, J., Deng, H., Wang, D., Chen, Z., \& Xu, S. (2013). Toxic heavy metal contamination and risk 485 assessment of street dust in small towns of Shanghai suburban area, China. Environmental Science 486 and Pollution Research, 20(1), 323-332.

487 Zhao, L., Xu, Y., Hou, H., Shangguan, Y., \& Li, F. (2014). Source identification and health risk 488 assessment of metals in urban soils around the Tanggu chemical industrial district, Tianjin, China. 489 Science of the Total Environment, 468, 654-662.

490 Zheng, N., Liu, J., Wang, Q., \& Liang, Z. (2010). Health risk assessment of heavy metal exposure to 491 street dust in the zinc smelting district, Northeast of China. Science of the Total Environment, 408(4), 726-733. 


\section{Figure captions}

Fig. 1. Location of street dust samples sites in the Dezful city.

Fig.2. Principal component analysis (PCA) of heavy metals in Dezful street dust Samples.

Fig. 3. Spatial distribution of heavy metals in Dezful street dust.

Fig. 4. Spatial distribution of the potential ecological risk (Er) in Dezful city.

Figure 5. Spatial distribution of risk index (RI) of heavy metals in Dezful city

Figure 6. Non-Cancer Cumulative Risk (HI) of heavy metals in adults and children.

Figure. 7. Cancer risk (CR) of heavy metals in dust street in Dezful 


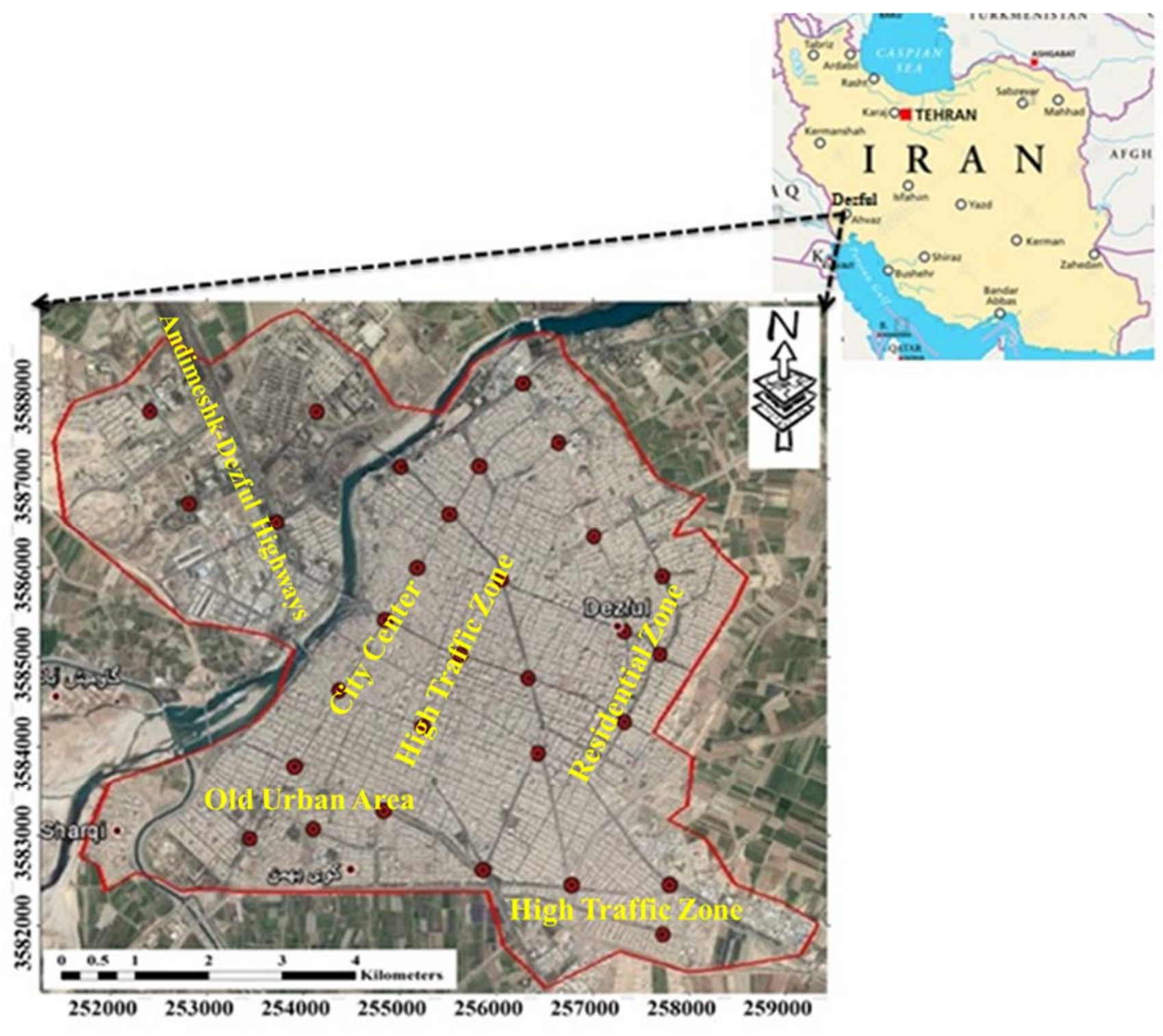

Figure1. 


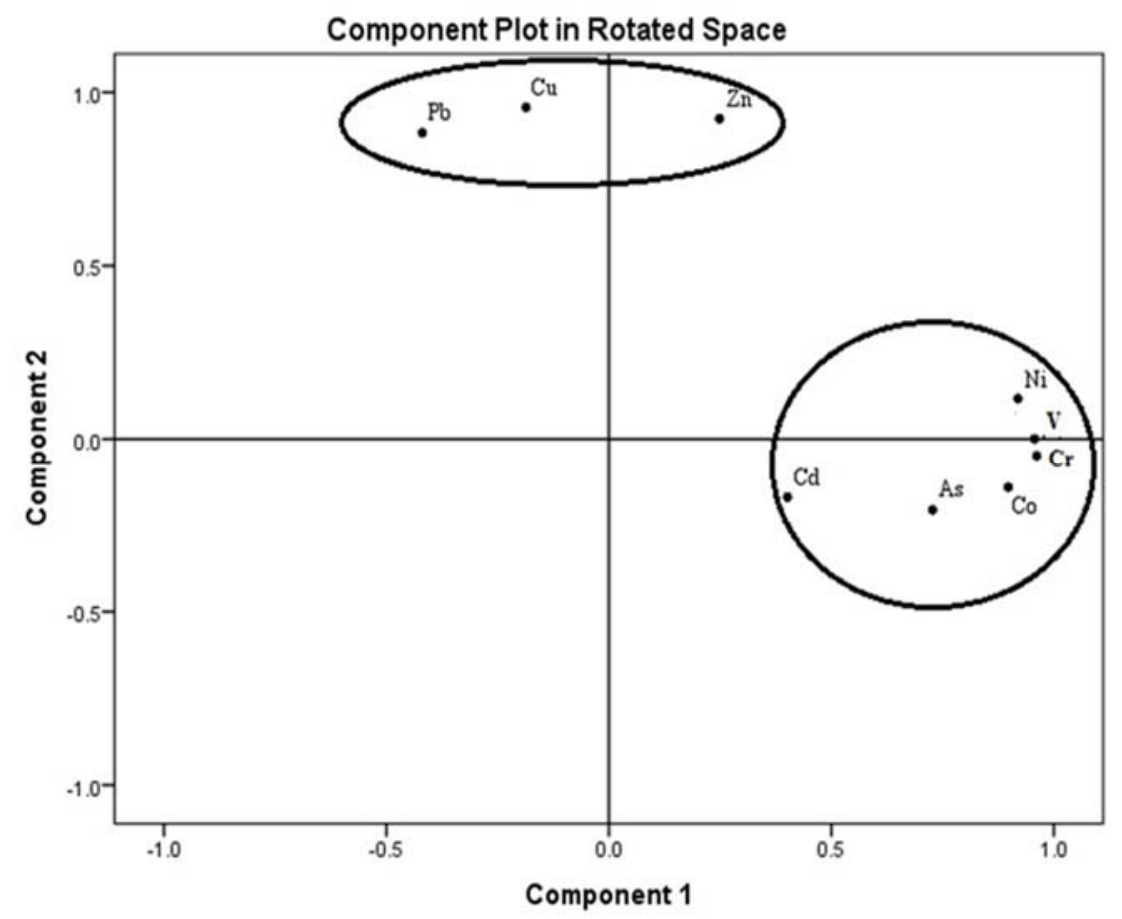

Figure 2. 

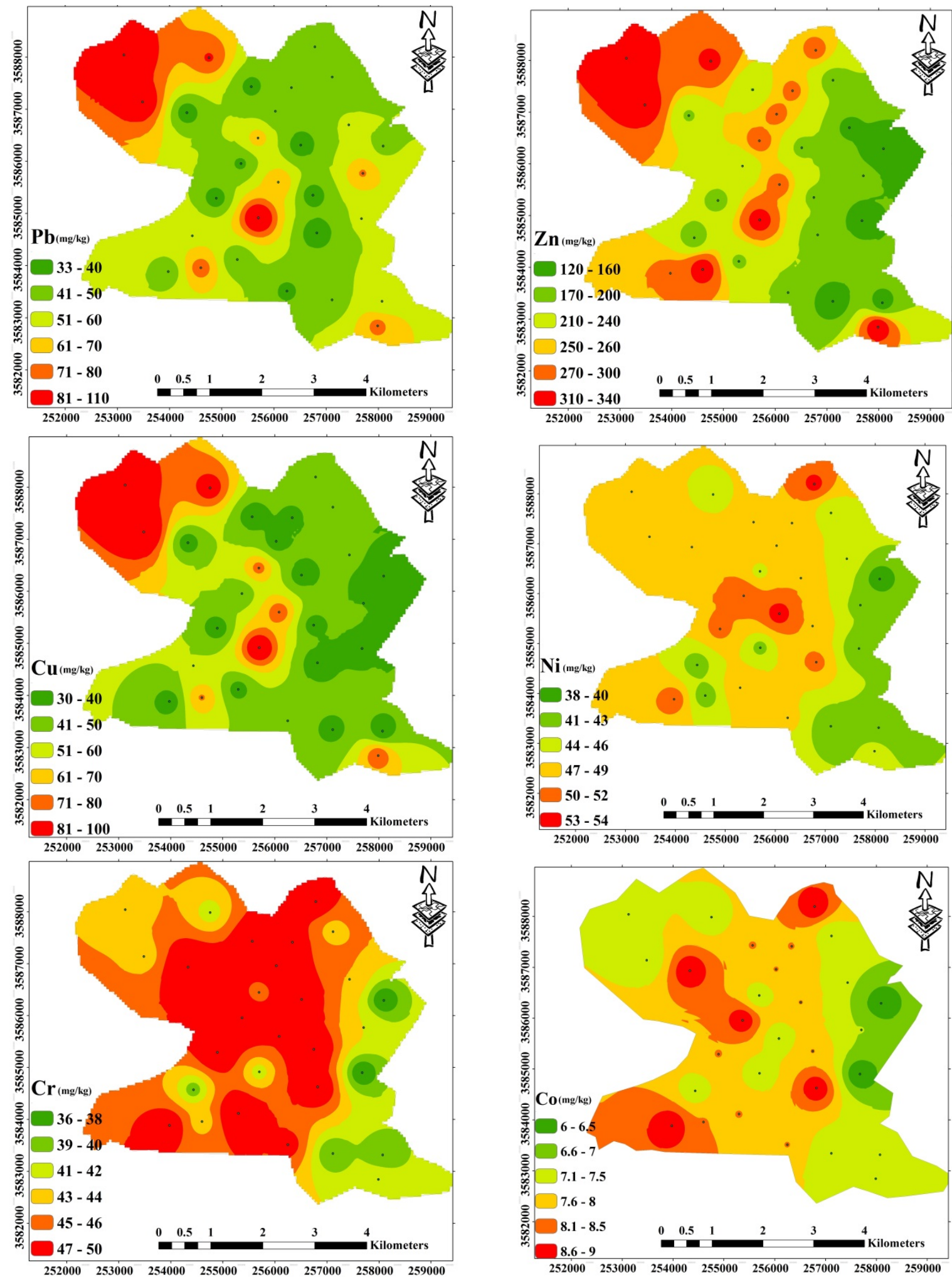

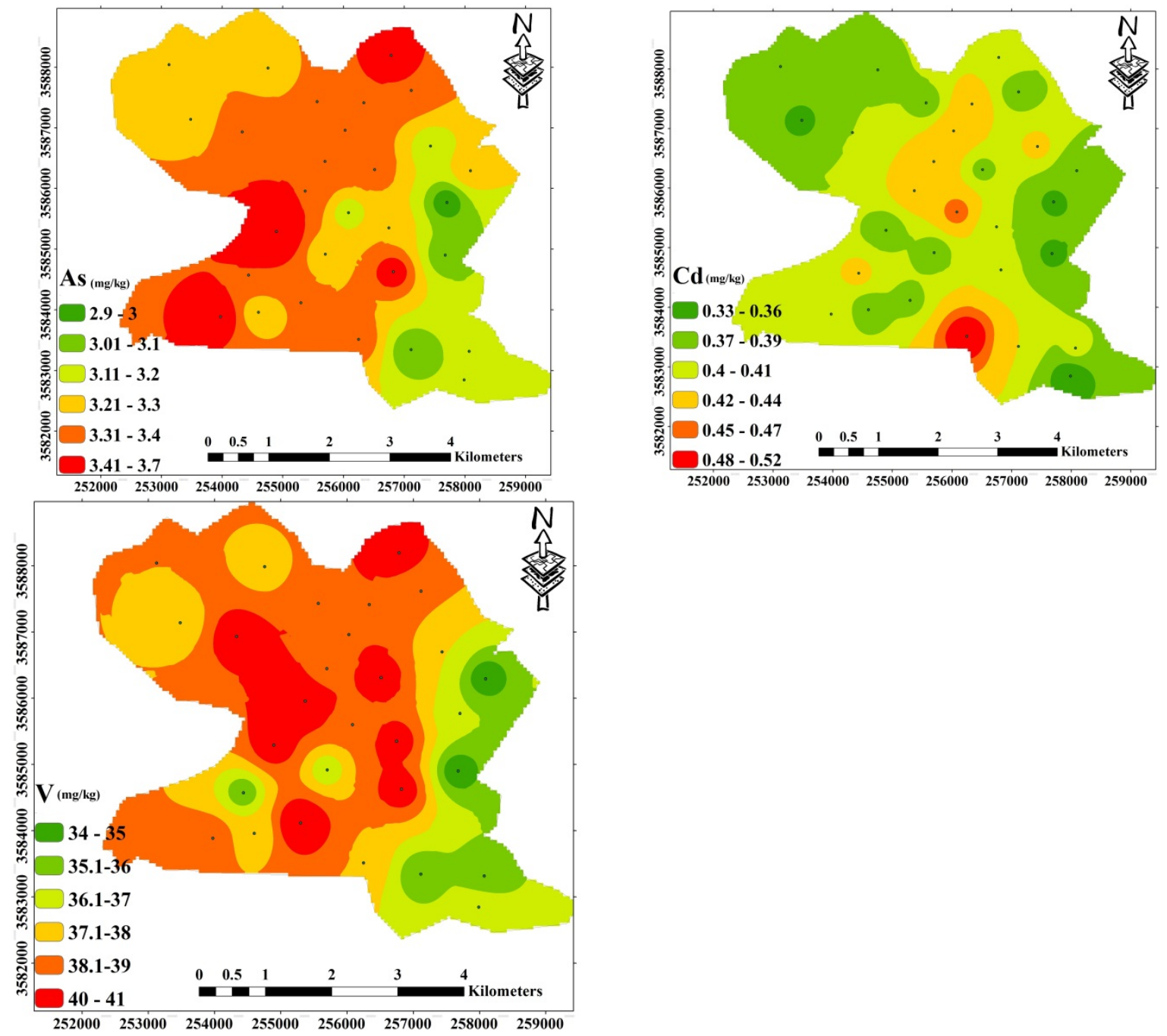

Figure 3. 

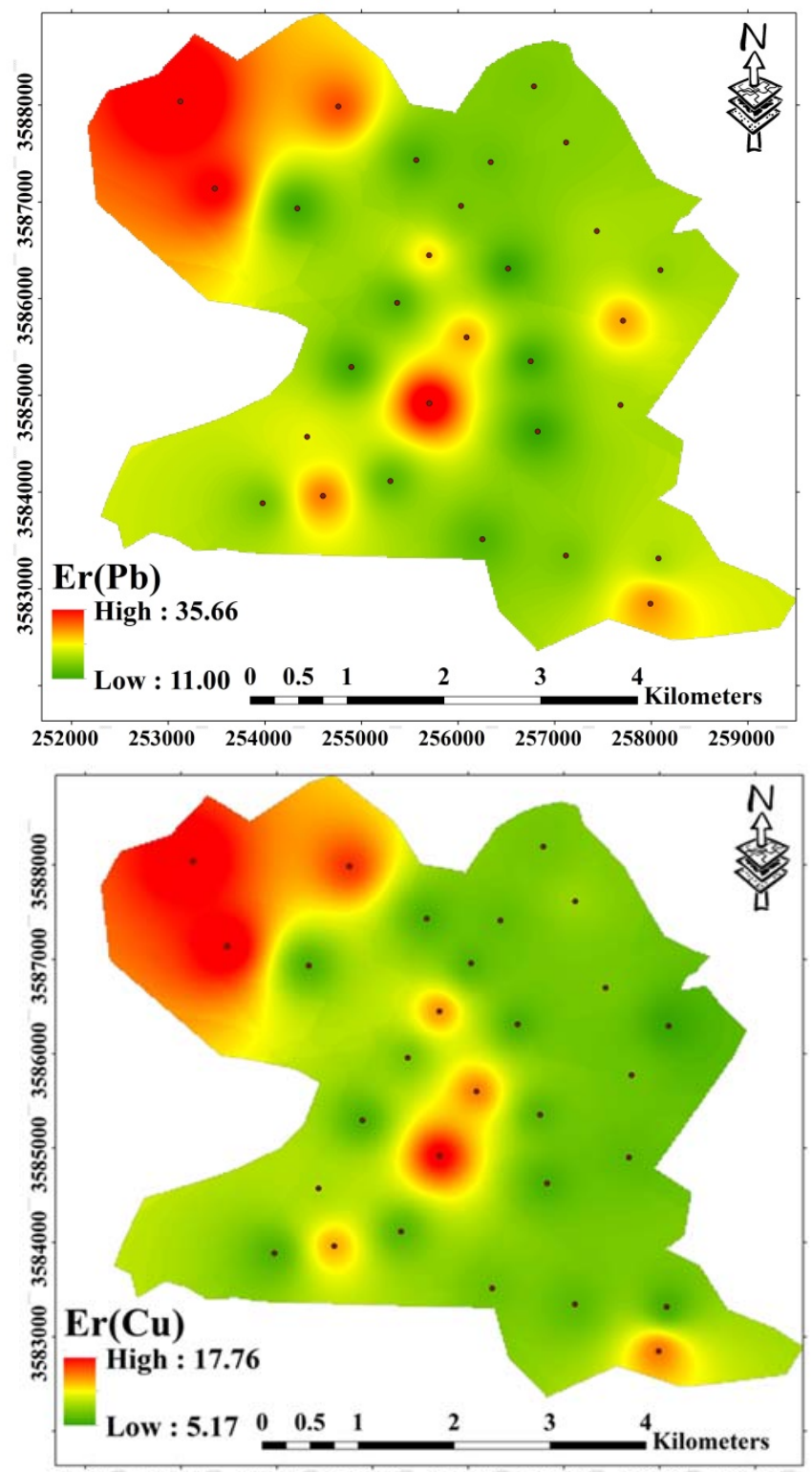

$\begin{array}{llllllll}252000 & 253000 & 254000 & 255000 & 256000 & 257000 & 258000 & 259000\end{array}$

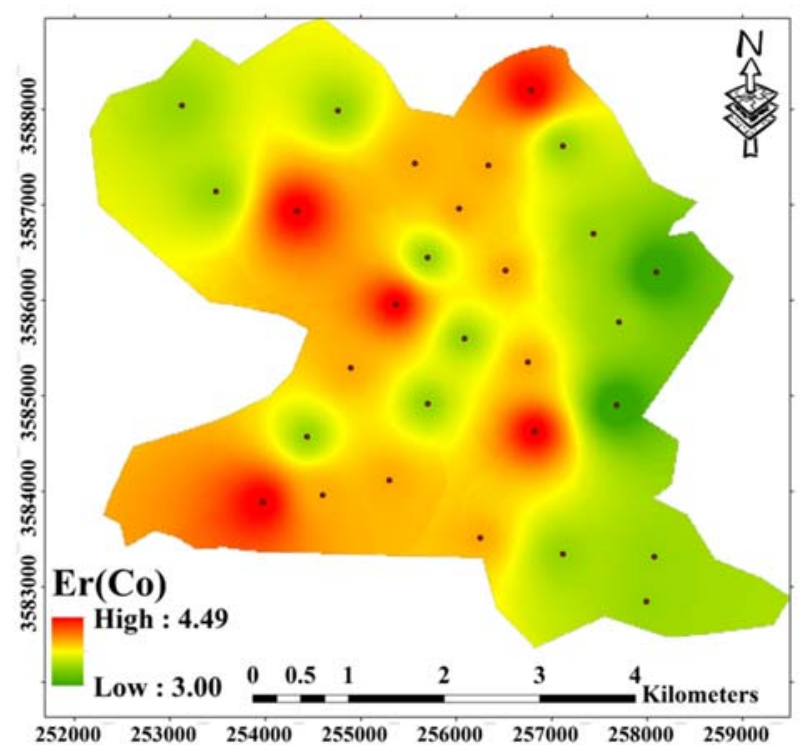

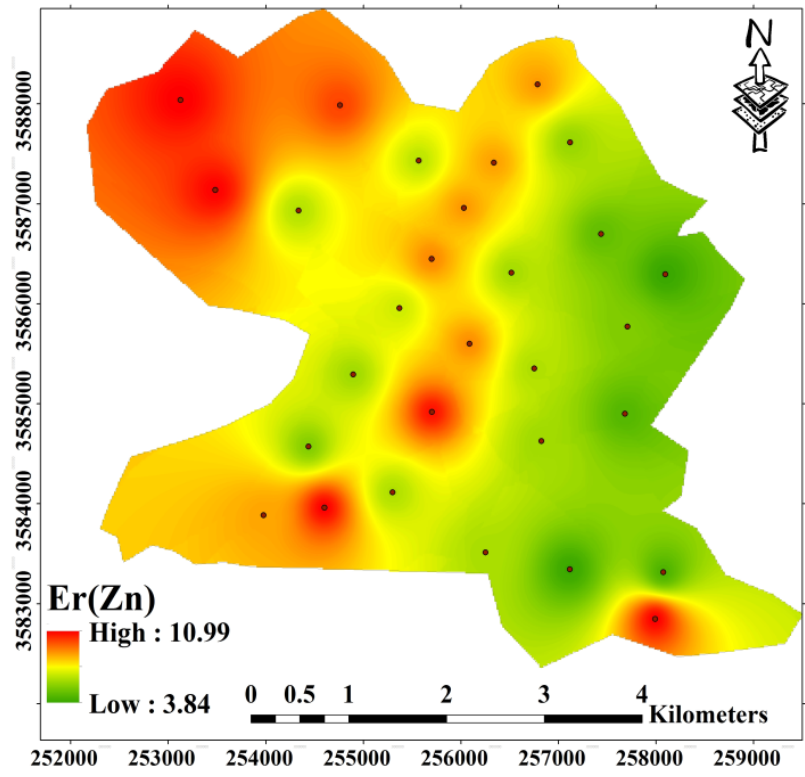
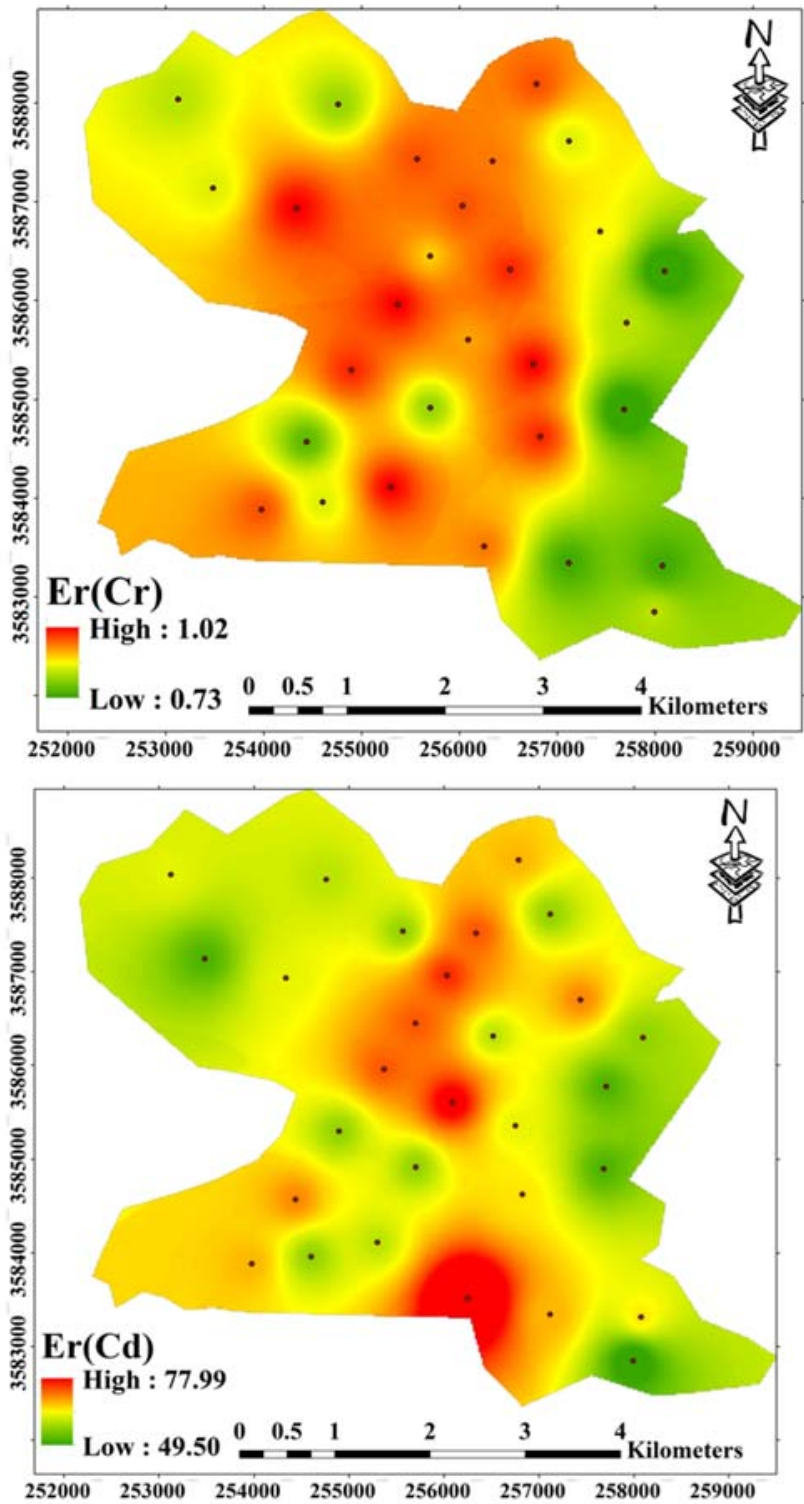

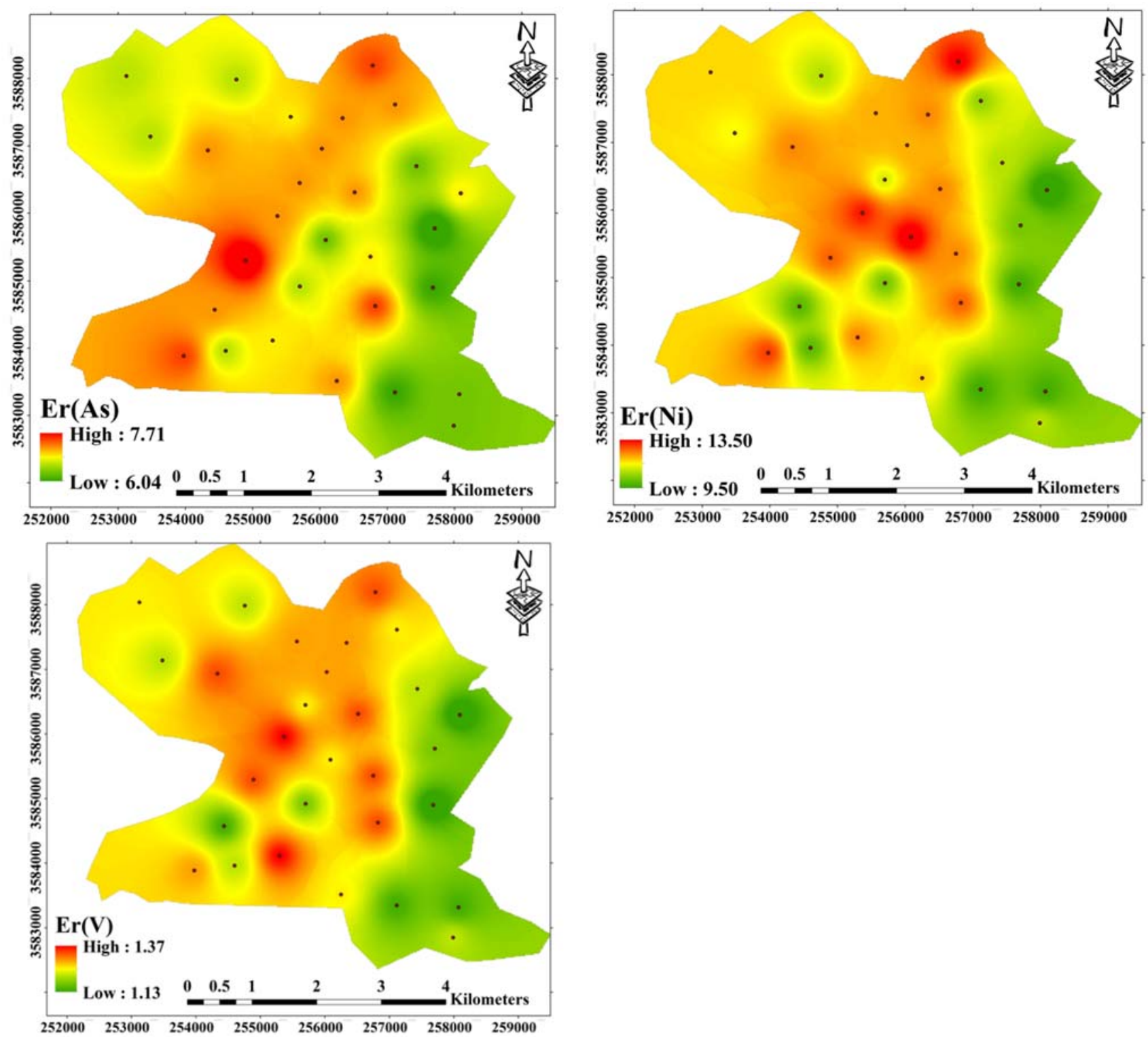

Figure 4. 


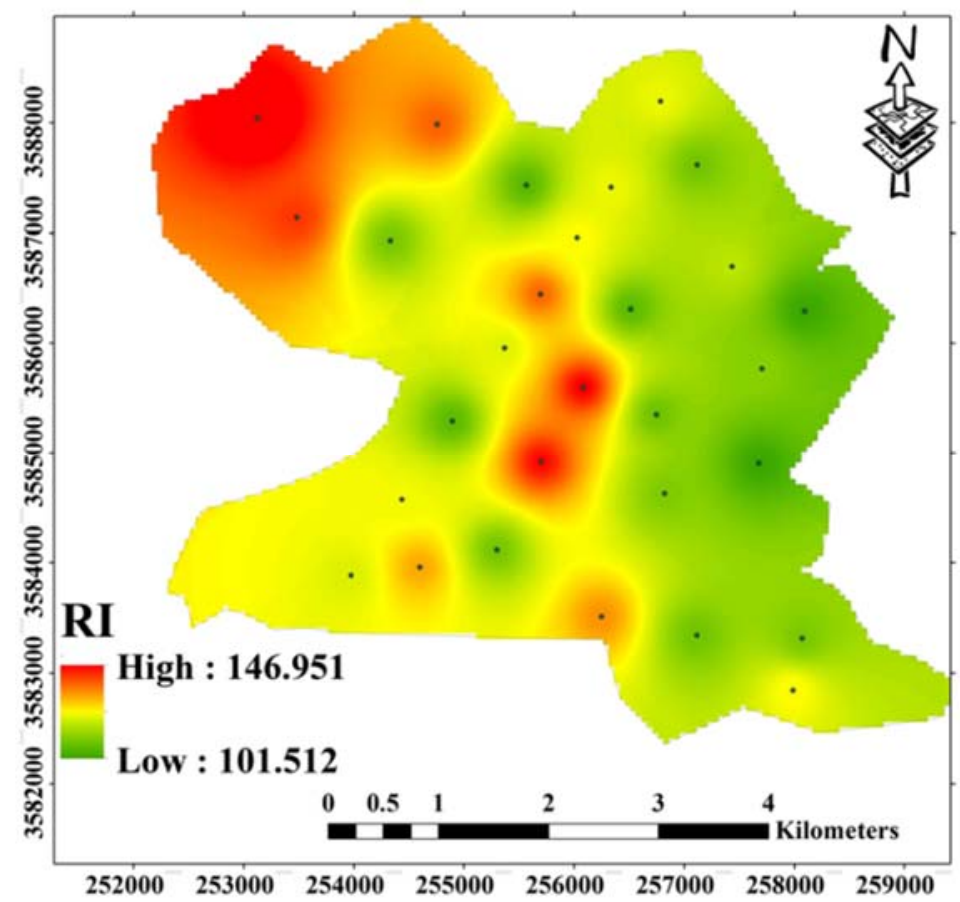

Figure 5. 


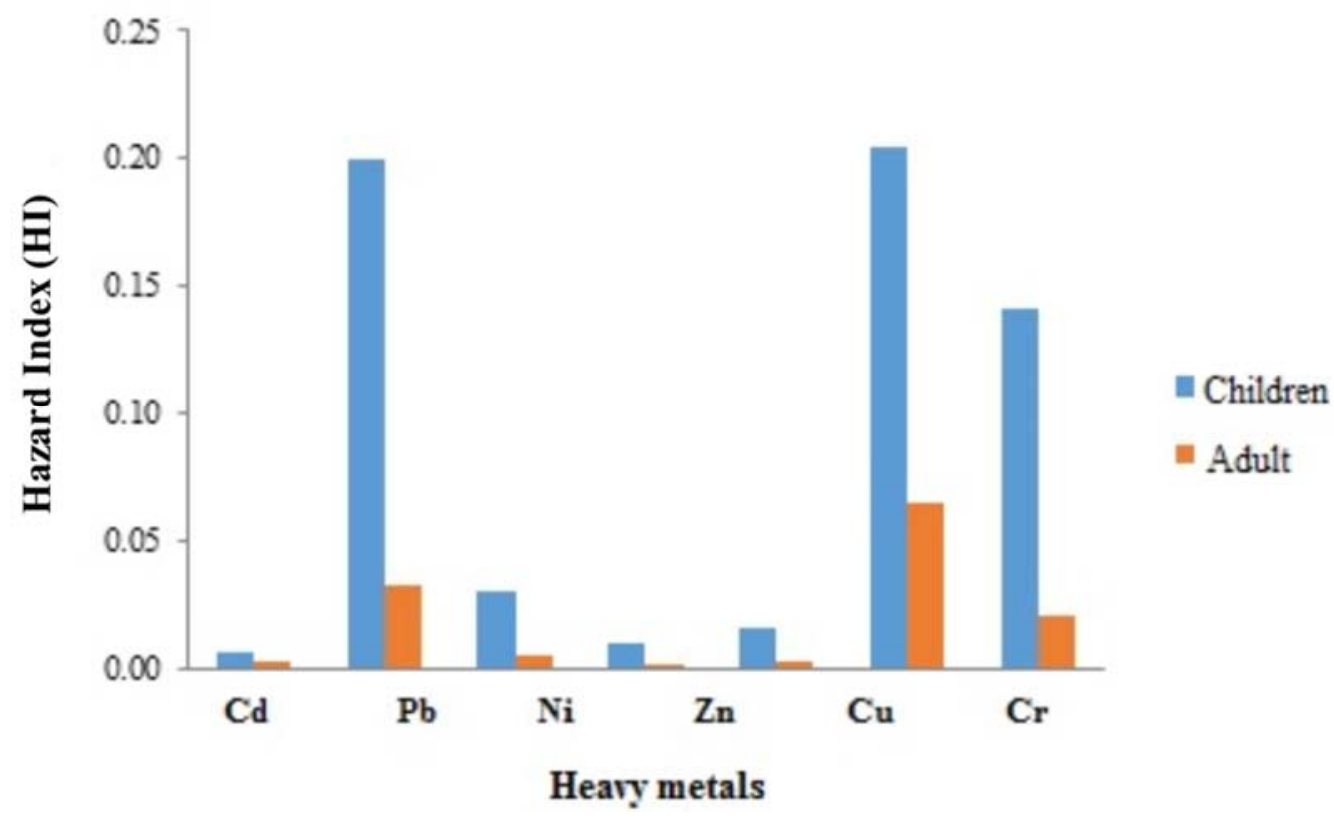

Figure 6. 


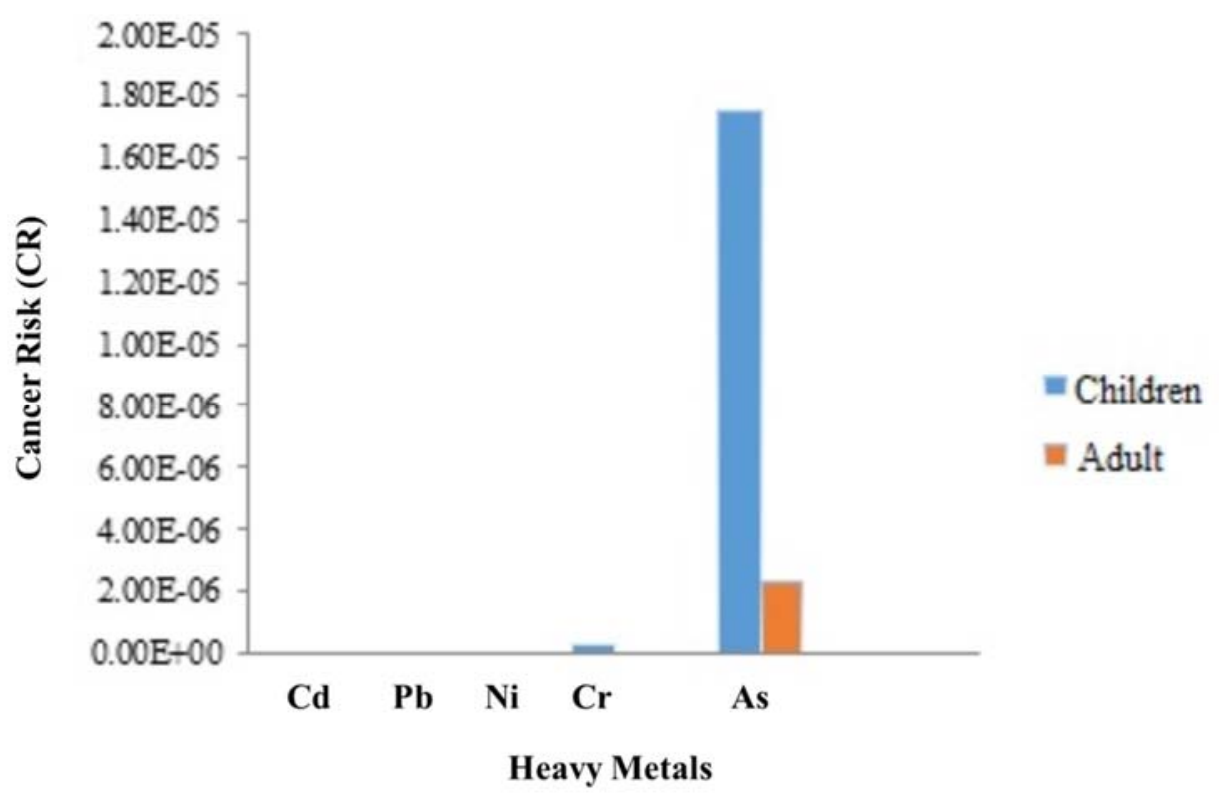

Figure 7. 


\section{Table captions}

Table 1. Exposure factor for metals doses.

Table 2. Summary metal concentrations in street dusts a from Dezful $(\mathrm{mg} / \mathrm{kg})$

Table 3. Mean concentrations of heavy metals in Dezful street dust samples and other selected cities $(\mathrm{mg} / \mathrm{kg})$.

Table 4. Correlation matrix for heavy metal concentrations in street dusts from Dezful.

Table 5. Statistical analysis of potential ecological risk factor (Er) of studied potentially heavy metals.

Table 6. Potential ecological risk indices for street dust.

Table 7. Health risk factors from heavy metal in street dusts of Dezful. 
Table 1.

\begin{tabular}{llll}
\hline Factor & Unit & Adult & Children \\
\hline IngR & $\mathrm{mg} /$ day & 100 & 200 \\
$\mathrm{InhR}$ & $\mathrm{m}^{3 / \text { day }}$ & 12.8 & 7.63 \\
$\mathrm{EF}$ & day/year & 350 & 350 \\
$\mathrm{ED}$ & year & 24 & 6 \\
$\mathrm{BW}$ & $\mathrm{Kg}$ & 55.9 & 15 \\
$\mathrm{AT}$ & $\mathrm{days}$ & $\mathrm{ED} \times 365$ & $\mathrm{ED} \times 365$ \\
$\mathrm{EF}$ & $\mathrm{m}^{3} / \mathrm{kg}$ & $1.36 \mathrm{E}+09$ & $1.36 \mathrm{E}+09$ \\
$\mathrm{SA}$ & $\mathrm{cm}^{2}$ & 4350 & 1600 \\
$\mathrm{AF}$ & $\mathrm{mg} / \mathrm{cm}^{2}$-day & 0.7 & 0.2 \\
$\mathrm{ABF}$ & - & 0.001 & 0.100 \\
\hline
\end{tabular}


Table 2.

\begin{tabular}{cccccc}
\hline Element & Unit & Min-Max & Mean \pm SD & Skewness & Upper crust content $^{\mathrm{a}}$ \\
\hline $\mathrm{Pb}$ & $(\mathrm{mg} / \mathrm{kg})$ & $33-107$ & $54 \pm 21$ & 1 & 15 \\
$\mathrm{Zn}$ & $(\mathrm{mg} / \mathrm{kg})$ & $119-341$ & $224 \pm 71$ & 0.4 & 31 \\
$\mathrm{Cu}$ & $(\mathrm{mg} / \mathrm{kg})$ & $30-103$ & $51 \pm 23$ & 1 & 29 \\
$\mathrm{Cr}$ & $(\mathrm{mg} / \mathrm{kg})$ & $36-50$ & $44 \pm 4$ & -0.4 & 35 \\
$\mathrm{Cd}$ & $(\mathrm{mg} / \mathrm{kg})$ & $0.3-0.5$ & $0.4 \pm 0.1$ & 1 & 0.1 \\
$\mathrm{Ni}$ & $(\mathrm{mg} / \mathrm{kg})$ & $38-54$ & $46 \pm 4$ & -0.04 & 20 \\
$\mathrm{~V}$ & $(\mathrm{mg} / \mathrm{kg})$ & $34-41$ & $38 \pm 2$ & -0.3 & 60 \\
$\mathrm{As}$ & $(\mathrm{mg} / \mathrm{kg})$ & $3-4$ & $3 \pm 0.2$ & -0.1 & 4.8 \\
$\mathrm{Co}$ & $(\mathrm{mg} / \mathrm{kg})$ & $6-9$ & $8 \pm 0.8$ & 0.3 & 10 \\
\hline
\end{tabular}

a(Rudnick and Gao, 2003) 
Table 3.

\begin{tabular}{lllllllllll}
\hline Location & $\mathrm{Pb}$ & $\mathrm{Zn}$ & $\mathrm{Cu}$ & $\mathrm{Cr}$ & $\mathrm{Cd}$ & $\mathrm{Ni}$ & $\mathrm{As}$ & $\mathrm{Co}$ & $\mathrm{V}$ & Reference \\
\hline Tehran (Iran) & 257 & 873 & 225 & 34 & 11 & 35 & - & - & - & (Saeedi et al., 2012) \\
Isfahan (Iran) & 393 & 707 & 182 & 82 & 2 & 70 & 22 & 14 & - & (Soltani et al., 2015) \\
Shiraz (Iran) & 11 & 34 & 225 & 873 & 257 & 35 & - & - & - & (Keshavarzi et al., 2015) \\
(China) Nanjing & 103 & 394 & 123 & 126 & 1 & 56 & 13 & 11 & - & (Hu et al., 2011) \\
Hong Kong (China) & 120 & 3840 & 110 & 124 & - & 29 & 67 & 10 & 37 & (Yeung et al., 2003) \\
(Canada) Ottawa & 39 & 113 & 66 & 43 & 0.4 & 15 & 1 & 8 & - & (Rasmussen et al., 2001) \\
Amman (Jordan) & 976 & 410 & 250 & 18 & 1 & 16 & - & - & - & (Jiries, 2003) \\
Konya (Turkey) & 19 & 68 & 16 & 22 & - & 10 & - & 7 & 68 & (Kariper et al., 2019) \\
Madrid (Spain) & 1927 & 476 & 188 & 61 & - & 44 & - & - & - & (de Miguel et al., 1997) \\
Newcastel (UK) & 992 & 421 & 132 & - & 1 & 26 & 6 & - & - & (Okorie et al., 2012) \\
Oslo (Norway) & 180 & 412 & 123 & - & 1 & 41 & - & - & - & (de Miguel et al., 1997) \\
Dezful (this study) & 54 & 224 & 51 & 44 & 0.4 & 46 & 3 & 8 & 38 & - \\
\hline
\end{tabular}


Table 4.

\begin{tabular}{llllllllll}
\hline & $\mathrm{Pb}$ & $\mathrm{Zn}$ & $\mathrm{Cu}$ & $\mathrm{Cr}$ & $\mathrm{Cd}$ & $\mathrm{Ni}$ & $\mathrm{V}$ & $\mathrm{As}$ & $\mathrm{Co}$ \\
\hline $\mathrm{Pb}$ & 1 & & & & & & & & \\
$\mathrm{Zn}$ & $0.507^{* *}$ & 1 & & & & & & & \\
$\mathrm{Cu}$ & $0.751^{* *}$ & $0.638^{* *}$ & 1 & & & & & & \\
$\mathrm{Cr}$ & 0.378 & 0.246 & 0.248 & 1 & & & & & \\
$\mathrm{Cd}$ & 0.238 & 0.033 & 0.003 & $0.420^{*}$ & 1 & & & & \\
$\mathrm{Ni}$ & 0.271 & 0.388 & 0.065 & $0.869^{* *}$ & $0.426^{*}$ & 1 & & & \\
$\mathrm{~V}$ & 0.248 & 0.304 & 0.205 & $0.967^{* *}$ & $0.410^{*}$ & $0.892^{* *}$ & 1 & & \\
$\mathrm{As}$ & 0.103 & 0.071 & 0.331 & $0.621^{* *}$ & $0.559^{*}$ & $0.576^{* *}$ & $0.664^{* *}$ & 1 & \\
$\mathrm{Co}$ & 0.266 & 0.228 & 0.321 & $0.863^{* *}$ & $0.518^{*}$ & $0.766^{* *}$ & $0.851^{* *}$ & $0.696^{* *}$ & 1 \\
\hline
\end{tabular}

*Correlation is significant at the 0.05 level (2-tailed)

**Correlation is significant at the 0.01 level (2-tailed) 
Table 5.

\begin{tabular}{llllll}
\hline Element & Min & Max & Mean & Standard Deviation & Skewness \\
\hline $\mathrm{Pb}$ & 11 & 36 & 18 & 6.8 & 1.2 \\
$\mathrm{Zn}$ & 4 & 11 & 7 & 2.3 & 0.4 \\
$\mathrm{Cu}$ & 5 & 18 & 9 & 3.9 & 1.3 \\
$\mathrm{Cr}$ & 0.7 & 1 & 0.9 & 0.1 & -0.4 \\
$\mathrm{Cd}$ & 50 & 78 & 59 & 5.7 & 1.2 \\
$\mathrm{Ni}$ & 10 & 14 & 12 & 1.1 & -0.1 \\
$\mathrm{~V}$ & 1 & 1 & 1 & 0.1 & -0.3 \\
$\mathrm{As}$ & 6 & 8 & 7 & 0.4 & -0.1 \\
$\mathrm{Co}$ & 3 & 5 & 4 & 0.4 & 0.3 \\
\hline
\end{tabular}


Table 6.

\begin{tabular}{ccccccc}
\hline & RI & \multicolumn{5}{c}{ Number of samples } \\
\hline Min & Max & Mean & Low Risk & Moderate risk & Considerable risk & High risk \\
\hline 102 & 147 & 118 & $30(\% 100)$ & 0 & 0 & 0 \\
\hline
\end{tabular}


Table 7.

\begin{tabular}{|c|c|c|c|c|c|c|c|}
\hline$(\mathrm{mg} / \mathrm{kg})$ & $\mathrm{Pb}$ & $\mathrm{Zn}$ & $\mathrm{Cu}$ & $\mathrm{Cr}$ & $\mathrm{Cd}$ & $\mathrm{Ni}$ & As \\
\hline $\mathrm{C}(95 \% \mathrm{UCL})$ & 54 & 224 & 51 & 44 & 0.4 & 46 & 3 \\
\hline $\mathrm{RfD}_{\text {ing }}$ (mg/kg day) & $3.00 \mathrm{E}-03$ & $3.00 \mathrm{E}-01$ & $4.00 \mathrm{E}-02$ & $3.00 \mathrm{E}-03$ & $1.00 \mathrm{E}-03$ & $2.00 \mathrm{E}-02$ & $3.00 \mathrm{E}-04$ \\
\hline $\mathrm{RfD}_{\text {inh }}$ (mg/kg day) & $3.52 \mathrm{E}-03$ & $3.00 \mathrm{E}-01$ & $4.02 \mathrm{E}-02$ & $2.86 \mathrm{E}-05$ & $1.00 \mathrm{E}-03$ & $2.02 \mathrm{E}-02$ & $3.10 \mathrm{E}-04$ \\
\hline $\mathrm{RfD}_{\text {derm }}(\mathrm{mg} / \mathrm{kg}$ day $)$ & $5.25 \mathrm{E}-04$ & $6.00 \mathrm{E}-02$ & $1.20 \mathrm{E}-02$ & $6.00 \mathrm{E}-05$ & $1.00 \mathrm{E}-05$ & $5.40 \mathrm{E}-03$ & $1.23 \mathrm{E}-04$ \\
\hline $\begin{array}{l}\mathrm{SF}_{\text {inh }}(\mathrm{mg} / \mathrm{kg} \text { day })^{-1} \\
\text { Children }\end{array}$ & - & - & - & $4.20 \mathrm{E}+01$ & $6.30 \mathrm{E}+00$ & $8.40 \mathrm{E}-01$ & $1.51 \mathrm{E}+01$ \\
\hline $\mathrm{HQ}_{\text {ing }}$ & $1.98 \mathrm{E}-01$ & $9.52 \mathrm{E}-02$ & $1.61 \mathrm{E}-02$ & $1.89 \mathrm{E}-01$ & $5.11 \mathrm{E}-03$ & $2.92 \mathrm{E}-02$ & $1.40 \mathrm{E}-01$ \\
\hline $\mathrm{HQ}_{\text {inh }}$ & 5.52E-06 & 2.67E-07 & $4.50 \mathrm{E}-07$ & $5.56 \mathrm{E}-04$ & $1.43 \mathrm{E}-07$ & 7.97E-07 & $3.80 \mathrm{E}-06$ \\
\hline $\mathrm{HQ}_{\text {derm }}$ & $2.11 \mathrm{E}-03$ & 7.62E-05 & $8.60 \mathrm{E}-05$ & $1.51 \mathrm{E}-02$ & $8.18 \mathrm{E}-04$ & $1.73 \mathrm{E}-04$ & $5.47 \mathrm{E}-04$ \\
\hline $\mathrm{HI}=\sum \mathrm{HQ}_{\mathrm{i}}$ & $1.99 \mathrm{E}-01$ & $9.60 \mathrm{E}-03$ & $1.62 \mathrm{E}-02$ & $2.05 \mathrm{E}-01$ & $5.93 \mathrm{E}-03$ & $2.95 \mathrm{E}-02$ & $1.40 \mathrm{E}-01$ \\
\hline $\mathrm{CR}$ & $2.14 \mathrm{E}-08$ & - & - & $1.75 \mathrm{E}-05$ & 2.37E-08 & $3.62 \mathrm{E}-07$ & 4.64E-08 \\
\hline \multicolumn{8}{|l|}{ Adults } \\
\hline $\mathrm{HQ}_{\text {ing }}$ & $2.65 \mathrm{E}-02$ & $1.27 \mathrm{E}-03$ & $2.16 \mathrm{E}-03$ & $2.53 \mathrm{E}-02$ & $6.68 \mathrm{E}-04$ & $3.92 \mathrm{E}-03$ & $1.88 \mathrm{E}-02$ \\
\hline $\mathrm{HQ}_{\text {inh }}$ & $2.48 \mathrm{E}-06$ & $1.23 \mathrm{E}-07$ & $2.03 \mathrm{E}-07$ & $2.50 \mathrm{E}-03$ & $6.45 \mathrm{E}-08$ & $3.58 \mathrm{E}-07$ & $1.71 \mathrm{E}-06$ \\
\hline $\mathrm{HQ}_{\text {derm }}$ & $5.38 \mathrm{E}-03$ & $1.94 \mathrm{E}-04$ & $2.19 \mathrm{E}-04$ & $3.86 \mathrm{E}-02$ & $2.08 \mathrm{E}-03$ & 4.43E-04 & $1.39 \mathrm{E}-03$ \\
\hline $\mathrm{HI}=\sum \mathrm{HQ}_{\mathrm{i}}$ & $3.19 \mathrm{E}-02$ & $1.47 \mathrm{E}-03$ & $2.38 \mathrm{E}-03$ & $6.42 \mathrm{E}-02$ & $2.77 \mathrm{E}-03$ & $4.37 \mathrm{E}-03$ & $2.02 \mathrm{E}-02$ \\
\hline CR & $2.87 \mathrm{E}-09$ & - & - & $2.35 \mathrm{E}-06$ & $3.18 \mathrm{E}-09$ & $4.85 \mathrm{E}-08$ & $6.22 \mathrm{E}-09$ \\
\hline
\end{tabular}

